\title{
Is group work beneficial for producing creative designs in STEM design education?
}

\author{
Ji Han ${ }^{1}$ D Dongmyung Park ${ }^{2} \cdot$ Min Hua $^{3}$ - Peter R. N. Childs ${ }^{4}$
}

Accepted: 22 September 2021 / Published online: 4 October 2021

(c) The Author(s) 2021

\begin{abstract}
Creativity is a significant element in design education, and frequently a significant competency during recruitment for design professions. Group work and individual work are widely employed in higher education. Many studies have highlighted the merits of employing group work in design education, cultivating collaborative design abilities and fostering sought-after employability skills. Although the benefits of group work in design practice and education are widely recognised, few studies have shown evidence that group work outperforms individual work regarding creative design activities in higher education contexts. Therefore, the aim of this research is to explore whether group or individual work is more beneficial for fostering students in generating creative designs in STEM design education. A case study, involving two cohorts of second-year undergraduate students studying a UK Engineering degree Industrial Design programme, is reported. The case study compares the design outputs produced by the two cohorts tackling the same design challenge in a product design module but employing individual and group work, respectively. The case study results show that no significant differences have been found between the design outputs produced by group work and individual work, considering novelty, usefulness and overall creativity. Further analysis reveals that a student's academic performance is not significantly related to the level of creativity of the design produced. This research indicates design educators should employ both group and individual work to complement each other in design education, and suggests potential solutions to enhance students' design creativity.
\end{abstract}

Keywords Design education · Group work · Individual work · Creativity · Idea generation · Idea evaluation - Idea selection

Ji Han

Ji.Han@liverpool.ac.uk

1 School of Engineering, University of Liverpool, Liverpool L69 3BX, UK

2 Division of Design, Incheon National University, Incheon 22012, South Korea

3 USC-SJTU Institute of Cultural and Creative Industry, Shanghai Jiao Tong University, Shanghai 200240, China

4 Dyson School of Design Engineering, Imperial College London, London SW7 2DB, UK 


\section{Introduction}

Creativity is an essential feature of human intelligence (Cross, 2011), which plays a significant role in design for supporting problem-solving, initiating innovations, and it is closely related to business commercial performance (Childs \& Fountain, 2011; Sarkar \& Chakrabarti, 2011). It is defined as 'the process by which something so judged (to be creative) is produced' (Amabile, 1983), 'the production of novel, useful products' (Mumford, 2003), and 'the ability to imagine or invent something new of value' (Childs et al., 2006), while novelty and usefulness are the two core elements of creativity in the design context (Sarkar \& Chakrabarti, 2008). Creativity is often associated with ideas, while tangible and intangible creative products embody 'good ideas' (Goldschmidt \& Tatsa, 2005). Han et al. (2018b) described design as the bridge connecting creativity and economic benefit, and suggested the significance of producing creative ideas. Howard et al. (2011) claimed that producing creative ideas is essential to developing novel concepts and ultimately innovation. However, it is challenging for designers to come up with creative ideas, due to issues such as too many existing ideas and lack of creative minds (Childs, 2018).

Although creativity is commonly considered a highly valuable element in science, technology, engineering and mathematics (STEM) disciplines, it is often considered associated more closely with arts than STEM education (Kind \& Kind, 2007; Li et al., 2019). Larkin (2015) pointed out that there is a great demand for creative engineers and scientists, but creativity is not often used to characterise an engineer or a scientist. Cropley (2015) indicated that there is a disconnection between creativity and engineering. However, creativity is becoming more important in the current STEM education. Many new problems have emerged, as well as rapid changes in technologies and society, requiring new solutions, which are not amenable to resolution by replicating old approaches. The exploration of new solutions for solving these emerging problems needs creativity (Bozkurt Altan \& Tan, 2020; Cropley, 2015). Teaching creativity in STEM education is significant for fostering STEM graduates with the abilities and skills to solve emerging problems and create innovations. It is therefore important to explore how creativity could be better fostered in STEM education.

Creativity has become a research hotspot and trend in the International Journal of Technology and Design Education since the early 2000s, while design, education, design education and creativity are the most frequently used keywords (Xu et al., 2020). For instance, Howard-Jones (2002) proposed a dual-state model of creative cognition to support fostering creativity in the classroom. Cropley and Cropley (2010) highlighted the importance of recognizing and fostering creativity in technological design education. Lu (2017) examined the effects of environmental experience on innovative cognitive style and students' creative outputs. Gray et al. (2019) demonstrated the use of a cognitive support method to support students in creative idea generation even after the students' ideas are exhausted. This shows the interest in exploring how creativity is fostered and the elements that encourage creativity, especially in design, technology and engineering education. Besides, Yang et al. (2005) indicated that creativity is one of the top five competencies for the overall industrial design profession during recruitment. However, creativity remains a notoriously elusive phenomenon in design education, which is often considered closely associated with human genius and serendipitous discovery.

Group and individual work are the two main learning strategies employed in university teaching. Group work has universal appeal in higher education, while individual work could cultivate a student's independent thinking (Almond, 2009). In this paper, group work 
refers to small group work, where teachers facilitate student-driven activities (Kirschner, 2001). Burke (2011) summarised that working as a group could have more information than individuals, stimulate creativity, remember group discussions better, yield greater satisfaction, understand better self-knowledge, and foster sought-after employability skills. An increasing number of firms are also seeking employees with collaborative group working skills (Algashaam, 2015; Almond, 2009; Pfaff \& Huddleston, 2003). A number of researchers have explored the use of group work in design education, such as Lee et al. (2017), Tucker (2017) and Qu et al. (2019), but few have compared group work and individual work in terms of teaching design creativity.

The aim of this research is to explore whether group work is better at fostering students with design creativity in producing design outputs in the product development context in STEM design education in comparison with individual work. In this research, we hypothesise:

Hypothesis 1. Group work in product development modules can lead to design outputs that are more novel comparing with individual work.

Hypothesis 2. Design outputs produced by group work are more useful than the ones produced by individual work.

Hypothesis 3. The overall creativity of design outputs produced by group work is better than the ones produced by individual work.

A practical case study has thereby been conducted to examine the hypotheses, which involves two cohorts of students tackling the same design challenge in a product design module but employing group and individual work respectively and followed by statistical analysis. The empirical results of the research lead to a better understanding of creativity in STEM design education and provides educators with potential suggestions on how to deliver STEM design modules.

The following "Theoretical background" section reviews related studies of group work and design creativity in education. The case study of group and individual work in STEM design education on creativity is detailed in "Case study method" section and followed by results in "Results" section. The discussion, implications and limitations of the study are indicated in "Discussion" section. The paper is then concluded in the last section.

\section{Theoretical background}

\section{Design creativity}

Creativity in design, or design creativity, is a significant element for new product development, which occurs between the problem and solution space (Demirkan \& Afacan, 2012). It is widely considered an essential part of the conceptual design stage where successful designs are often originated from (Chiu \& Shu, 2012; Crilly \& Moroşanu Firth, 2019; Thompson \& Lordan, 1999; Toh \& Miller, 2015). However, there is a long-term debate surrounding the definition of creativity in classical research fields (such as psychology and cognitive science) and design research. Han et al. (2021) reviewed over 50 studies in various fields, with a particular focus on design, to explore how creativity is defined and 
assessed. They revealed that novelty and usefulness are consistently used as the core elements for defining and assessing creativity across the board. Novelty refers to both newness and originality, while usefulness refers to quality, feasibility and value (Chiu \& Shu, 2012; Girotra et al., 2010; Han et al., 2021; Sarkar \& Chakrabarti, 2011; Shah et al., 2003). Although Gero et al. (2019) argued that surprise should be included as the third element of design creativity for measuring the unexpectedness of a design, many other researchers, including Chiu and Shu (2012), Zheng and Miller (2020) and Koronis et al. (2019), indicated surprise as a nuance of novelty. Therefore, novelty and usefulness are considered the two key elements of design creativity. In other words, design creativity refers to the generation of novel and useful products, which is in line with the common design creativity definition by Sarkar and Chakrabarti (2008). Few studies have explored the links between novelty and usefulness, of which He and Luo (2017) found that an inventive design's novelty profile can influence its usefulness value, while Han et al. (2021) showed that there are no significant relations between a product's novelty and usefulness.

Innovation is a crucial factor for commercial success and viability in a competitive market (Bruton, 2011; Guo et al., 2017), which is highly related to product development. Creativity and innovation are often discussed simultaneously in design research, while creativity is considered central to innovative product development (Crilly \& Moroşanu Firth, 2019; Shai et al., 2009). Moreover, Sarkar and Chakrabarti (2011) showed that creativity is considered the prerequisite for product innovation, Cropley et al. (2011) indicated that creative product is the initial point for product innovation, and Starkey et al. (2016) claimed that successful innovation depends on creative design ideas. This has implied that design creativity is a key driver of product innovation, ultimately leading to business success and commercial benefits. Cultivating design creativity to prepare students to be innovative designers and design engineers is thereby significant for design education.

\section{Group work in education}

Group work is a popular teaching strategy in higher education, and it is commonly asserted that students need collaborative group working experience prior to employment (Almond, 2009). Benefits frequently highlighted include that it can foster students' abilities and skills in oral communication, written communication, collective decision making, group management, interpersonal dynamics issues, critical reflection, self-directed learning, and social interactions (Almond, 2009; Boud et al., 1999; Burke, 2011; Gupta, 2004). These skills and abilities are not discipline-specific but are transferable that could benefit lifelong learning. Although students generate one final 'product' in group work, it still provides opportunities for individuals to learn related concepts and knowledge (Pfaff \& Huddleston, 2003). In addition, students are also able to learn from each other in several ways, such as giving and receiving help, sharing knowledge, observing others, and building on each other's ideas, which will increase their knowledge and understanding (Webb \& Mastergeorge, 2003). Mbalamula (2018) indicated that students perform better in groups than individuals, and the students' scores increase while the number of students in a group increases. Group work also has the advantage of using limited resources effectively. For instance, Almond (2009) and Pfaff and Huddleston (2003) indicated that higher education institutions may reduce the material resources and marking effort by employing group work.

However, many researchers hold a sceptical view of the value of group work, despite its claimed benefits in higher education. Beebe and Masterson (2003) indicated that group work might cause issues such as peer pressure to conform to majority opinions, individuals 
dominating discussions, some members relying heavily on others, and time-consuming compared with individual work. Bacon (2005) indicated that students learned less in group projects than in individual projects. Pauli et al. (2008) claimed that motivational, interactional, and logistical difficulties are the main source of causing problems in group work. Lin et al., (2019) revealed that the two main flaws in group work projects are 'social loafing' and 'unfair mark'. 'Social loafing' refers to the phenomenon that people spend less effort in group work than individual work for achieving a goal. 'Unfair mark' refers to the marks, which cannot truly reflect each individual's contribution, given to the group members. One of the common methods to address the issues arisen in group work is to perform self and peer assessment among students (Elliott \& Higgins, 2005). However, there are doubts about the usefulness of peer assessment, as indicated in the research conducted by Kennedy (2005) and King and Behnke (2005).

Several researchers have investigated the use of group work and individual work in different education settings. For example, Rickheim et al. (2002) showed that group work and individual work are equally effective at delivering key elements in medical health education, while group work is more cost-effective and efficient. Fernández Dobao (2012) revealed that groups perform better than individuals in terms of accuracy while conducting writing tasks. Cronin and McCabe (2017) showed that students working individually in laboratory-based science classes have significantly improved laboratory techniques in comparison with students working in groups. Lin (2019) indicated that students perform better in group work than individual work in terms of vocabulary learning, despite students prefer individual work. These examples show that the effects of group work vary in different educational contexts.

In design education, group work is employed to support students in experiencing and understanding collaborative design processes (Qu et al., 2019). The ability to work in a group is highly demanded by design practice (Thompson, 2002). Many design activities involve group work, especially when solving complex design problems (Daly et al., 2019). Early studies revealed that group work could lead to better clarifications of tasks, the generation of a large variety of ideas, and a more intensive analysis of the ideas generated, but dominant group members often influence group discussions, which might even interrupt group cooperation (Ehrlenspiel et al., 1997). In recent studies, Lee et al. (2017) investigated the cognitive challenges for design teams and their educators. Tucker (2017) proposed a framework for understanding the effectiveness of group work in design assignments, which supports educators to better integrate group work into their modules and evaluate learning outcomes. Qu et al. (2019) indicated that design educators are positive about the students' results and effort in group work. However, the learning outcomes of each individual in group work varies greatly, depending on the course set up, cognitive levels, commitments, and group role-related knowledge. Mattioli (2019) raised the attention of the extensive use of cross-culture design teams, including disciplinarily diverse, demographically diverse and cognitively diverse, in nowadays education. Group work tends to be a widely used approach in design education (Thompson, 2002) with an increasing research interest, but whether group work is a beneficial approach for educating design creativity needs further investigation.

\section{Creativity in design education}

Creativity plays a significant role in practical design and is presented in all stages of the design process, including detailed design (Court, 1998). Several studies have explored 
the impacts of group work and individual work on creative design activities. Court (1998) indicated that group methods are favoured, while it is important to create a suitable environment and construct multidisciplinary groups. Taggar (2002) showed that the combinations of contributions from the individual group members at group level could lead to ideas that are more creative. Kohn et al. (2011) indicated that groups outperform individuals on idea combination, generating more novel and feasible outputs. Bissola and Imperatori (2011) showed that designers with poor individual creative skills can perform well in groups if organised properly. McMahon et al. (2016) also showed that it is beneficial to develop ideas in collaborative groups compared with individuals. By conducting a real-life setting case study, Petersson et al. (2017) revealed that group work is beneficial for the analysis of design topics and the generation of ideas to address the topics. However, researchers, such as Stroebe et al. (2010) and Putman and Paulus (2009), held the view that individuals are more creative and perform better in brainstorming compared with groups. Nevertheless, Linsey et al. (2011) indicated that individual and group work are both important in idea generation.

Design education is considered the base of knowledge about design creativity (Rauth et al., 2010). Therefore, fostering design students with creative skills and methods is considered an important part of their education stage and future careers. In addition, creativity is also considered a significant element of the UK design course accreditation criteria of the Institution of Engineering Designers (IED) and the Chartered Society of Designers (CSD) (Dowlen, 2019).

Producing ideas is essential in design, which has a significant impact on the success of a product. It is revealed that there is a strong link between the raw ideas of a product and the consumers' purchase intent of the product (Kornish \& Ulrich, 2014). However, it can be challenging for designers to come up with creative ideas, particularly design students (Wong \& Siu, 2012). Therefore, educating students with creative idea generation skills and methods plays a significant role in the curriculum of design education. Many studies have investigated how to prepare students with the ability to generate creative ideas, as it significantly affects the quality of the final creative outputs (Zhang et al., 2015). For example, Hernandez et al. (2014) investigated the use of TRIZ, Sketching and Smartpen in a design course, and indicated all three aids had enhanced the effectiveness of students' idea generation while TRIZ was the best in improving novelty; and Daly et al. (2019) showed the use of the 77 Design Heuristics (Yilmaz et al., 2016) in design classrooms could support the exploration of more innovative ideas. Many creativity tools or ideation techniques are employed in design classes for supporting design students in creative idea generation, which involves:

- Bio-inspired Design (Chakrabarti \& Shu, 2010; Helms et al., 2009)

- Brainstorming (Osborn, 1979)

- C-Sketch (Shah et al., 2001)

- Lateral Thinking (De Bono, 2010)

- Method 6-3-5 (Rhorbach, 1969)

- Mind Mapping (Buzan, 2006)

- Morphological Analysis (Zwicky, 1969)

- SCAMPER (Eberle, 1996)

- Six Thinking Hats (De Bono, 1985)

- TRIZ (Altshuller, 1984) 
However, some of the tools are suitable for group work while some others are more suitable for individuals. For examples, six thinking hats (De Bono, 1985), C-sketch (Shah et al., 2001), and brainstorming (Osborn, 1979) including its variations, such as brain-writing, sticky note and flip chart brainstorming, are more suitable for groups than individuals. Creativity tools, such as TRIZ (Altshuller, 1984), are more suitable to be used by individuals rather than groups. Linsey et al. (2005) showed that group idea generation techniques, such as C-Sketch, could support designers in generating ideas with a larger quantity and better quality. In addition to these conventional idea generation techniques, computational creativity support tools have been developed in recent years for supporting designers in creative idea generation, such as Idea Inspire 4.0 (Siddharth \& Chakrabarti, 2018), the Retriever (Han et al., 2018b), the Combinator (Han et al., 2018a), and InnoGPS (Luo et al., 2019). Although most of these computational tools are aimed for supporting individual designers, few of the tools have been employed in the current design education.

Design creativity assessment is also central to the curriculum of design education, which often occurs while students are developing their design ideas and concepts (Georgiev \& Casakin, 2019). In design practice, many methods, involving Consensual Assessment Technique (CAT) (Amabile, 1982) and Creative Product Semantic Scale (CPSS) (O'Quin $\&$ Besemer, 1989), are often employed to assess the degree of creativity for product ideas and concepts. In design education, students evaluate the ideas generated and select the best or the most preferred one by employing idea evaluation and selection methods, which are not aimed at assessing creativity specifically, rather than using design creativity assessment methods. However, idea evaluation and selection is still considered a challenging task for students, which involves compromise, judgment and risk (Oman et al., 2013). Furthermore, many textbooks used by educators for teaching STEM design courses, including the 'Engineering Design: A Systematic Approach' (Pahl \& Beitz, 2013), the 'Delft Design Guide: Design Strategies and Methods' (Van Boeijen et al., 2014), and the 'Mechanical Design Engineering Handbook' (Childs, 2018), provide useful methods for evaluating and selecting ideas, but not considering creativity as a design requirement in general. Several methods often used in design education for idea evaluation and selection are listed as follows:

- Harris Profile (Harris, 1976)

- PMI-Positive, Negative, Interesting (De Bono, 2010)

- Pugh's Matrix (Pugh \& Clausing, 1996)

- SWOT-Strength, Weakness, Opportunity and Threat

- Tabular Evaluation Matrix (Childs, 2018)

- Voting System (Childs, 2018; Rebernik et al., 2008)

These idea evaluation and selection methods are often used by both groups and individuals. Faure (2004) showed that the quality or novelty of the ideas selected by a group of individuals and an interactive group do not have significant differences. However, Nijstad and De Dreu (2002) suggested that the selection of high-quality ideas performs better in groups rather than individuals. Rietzschel et al. (2006) indicated that idea selection is a judgment task, where group discussion could improve the selection process. They revealed that groups tend to select more novel ideas compared with individuals.

According to the preceding reviews, both group and individual work have their advantages and disadvantages, but group work tends to be more popular and effective in design education and creative design activities. However, few practical studies have been conducted that could provide the direct evidence. Therefore, a case study is conducted in the next section to yield more practical insights. 


\section{Case study method}

\section{Approach}

In order to investigate the three hypotheses proposed in this paper, a case study has been conducted to explore and compare the impacts of employing group work and individual work on design creativity. The case study involves two cohorts of year two undergraduate students studying the same product development module within an Engineering degree Industrial Design programme at a university in the UK. The two cohorts are provided with the same design project, while the first cohort employs group work and the second cohort employs individual work. The project assignments, in forms of design portfolios, produced by the two cohorts are assessed by the module teacher using the same marking rubric to ensure the two cohorts possess similar intellectual abilities for a fair comparison. Expert assessment is then introduced to evaluate the degree of creativity for the final designs produced and followed by statistical analysis for examining the three hypotheses. The participants, instruments and implementation of the case study are presented in the following sub-sections, while the results and statistical analysis are provided in "Results" section.

\section{Participants}

The first cohort (cohort A), which involves 32 students, studied the product development module in 2018/2019 academic year, while the second cohort (cohort B), which involves 30 students, studied the module in 2019/20 academic year. Both of the cohorts were taught by the same module teacher and used the same set of teaching materials. Students from both cohort $A$ and $B$ were admitted into the university under the same entry requirements, and studied the same set of modules in their year one studies.

The two cohorts were given the same design project 'a new manual juicer design' as their module assignment. Cohort $A$ was required to conduct their design projects in groups of four (8 groups in total), while students in cohort $B$ conducted their projects individually without any collaborations. However, students in cohort $B$ were also provided with the additional opportunity to work on projects of their own choices, such as 'a new garlic press design' or 'a new portable camera handle design'. 15 students in cohort $B$, who selected the 'a new manual juicer design' project, are included in the case study for comparison with the 8 groups of students in cohort $A$. The 15 students are named as cohort $B^{*}$ to distinguish from cohort $B$ in the following research. The remaining students, who worked on their own project choices, are excluded from the case study. This is to deliver a fair comparison between the final designs produced by students employing group work and individual work.

The participant demographic information of cohort $A$ and $B$, including $B^{*}$, is provided in Table 1. The age of a student is calculated based on the student's date of birth and the date that the module started. Please note that a mature student was involved in cohort $B$ but not cohort $B^{*}$. All the students signed up with standard case study protocols giving permission to use the data. However, the intellectual properties of the designs created by the students are owned by themselves according to the University's Intellectual Property Policy. 
Table 1 Participant demographic information

\begin{tabular}{lllll}
\hline & $\begin{array}{l}\text { Number of } \\
\text { participants }\end{array}$ & Average age (SD) & \multicolumn{2}{l}{ Gender } \\
\cline { 3 - 5 } & & & Male & Female \\
\hline Cohort $A$ & 32 & $20.35(0.61)$ & 16 & 16 \\
Cohort $B$ & 30 & $20.84(1.73)$ & 17 & 13 \\
Cohort $B *$ & 15 & $20.44(0.51)$ & 8 & 7 \\
\hline
\end{tabular}

SD: standard deviation

\section{Design of instruments}

In the product development module, marking rubrics were distributed to both cohorts at the beginning of the module to provide students with the information regarding the marking criteria, which were used to assess the students' portfolios produced. The rubrics are also employed in the case study as the instrument for measuring the students' intellectual abilities.

Comparing with the marking rubric used to assess cohort $A$ in $2018 / 2019$ academic year, as shown in Fig. 1a, a slightly different version was used to assess cohort $B$ in 2019/2020 academic year, as shown in Fig. 1b. Both of the rubrics contain the same set of main marking criteria, 'portfolio presentation', 'design phase and outcome', and 'presentations of design', of which each criterion contains a sub-set of marking items. Two marking items in the criterion 'design phase and outcome', 'concept generation and selection' (10\% marking weighting) and 'demonstration of concepts' (10\% marking weighting), in the marking rubric for cohort $A$ were combined into 'concept generation, selection and demonstration' in the one used for cohort B, but maintained the same overall weighting of $20 \%$.

\begin{tabular}{|c|c|}
\hline Criteria & Items \\
\hline \multirow{2}{*}{$\begin{array}{l}\text { Portfolio } \\
\text { Presentation } \\
\text { (20\%) }\end{array}$} & $\begin{array}{l}\text { Structure and content (10\%) } \\
\text { Effective communication of project aim, context, design } \\
\text { process, appropriate content, final design solution. }\end{array}$ \\
\hline & $\begin{array}{l}\text { Visuals and delivery (10\%) } \\
\text { Quality of portfolio presentation. Quality of visuals, images, } \\
\text { tables, and so on. Professional layout and format. }\end{array}$ \\
\hline \multirow{6}{*}{$\begin{array}{l}\text { Design Phase } \\
\text { and Outcome } \\
\quad \text { (50\%) }\end{array}$} & $\begin{array}{l}\text { Understanding of design problems ( } 5 \% \text { ) } \\
\text { Contextual framing of the project, responding to the design } \\
\text { brief. }\end{array}$ \\
\hline & $\begin{array}{l}\text { Background research and requirement analysis (10\%) } \\
\text { Identification of design background, areas and requirements. }\end{array}$ \\
\hline & $\begin{array}{l}\text { Demonstration of design process (5\%) } \\
\text { Quality of design and development processes, design } \\
\text { iterations, gradual resolution towards fully-specified design, } \\
\text { user testing and feedback. }\end{array}$ \\
\hline & $\begin{array}{l}\text { Concept generation and selection (10\%) } \\
\text { Effective use of idea generation and selection methods, } \\
\text { diversity of solutions, concept evaluation and decision } \\
\text { making. }\end{array}$ \\
\hline & $\begin{array}{l}\text { Demonstration of engineering knowledge (10\%) } \\
\text { Consideration of engineering aspects, feasibility, structural } \\
\text { analysis, mechanism, material selection, manufacturability, } \\
\text { assembly, durability, reliability, risk consideration. }\end{array}$ \\
\hline & $\begin{array}{l}\text { Demonstration of concepts (10\%) } \\
\text { Demonstrating the theory and rational underpinning them, } \\
\text { consideration of context of use, human factors, satisfaction of } \\
\text { user needs, creativity. }\end{array}$ \\
\hline $\begin{array}{l}\text { Presentations } \\
\text { of Design } \\
\text { (30\%) }\end{array}$ & $\begin{array}{l}\text { Sketches, drawings, and prototype (30\%) } \\
\text { Effective use of sketches, storyboarding, mock-ups, CAD } \\
\text { drawings, visualisation and language, aesthetics throughout } \\
\text { the portfolio. The quality of your final prototype: evidence of } \\
\text { consideration of context of use, aesthetics, styling, and } \\
\text { consideration of engineering calculations and drawings, } \\
\text { functionality. }\end{array}$ \\
\hline
\end{tabular}

(a)

\begin{tabular}{|c|c|}
\hline Criteria & Items \\
\hline \multirow{2}{*}{$\begin{array}{l}\text { Portfolio } \\
\text { Presentation } \\
\quad(20 \%)\end{array}$} & $\begin{array}{l}\text { Structure and content (10\%) } \\
\text { Effective communication of project aim, context, design } \\
\text { process, appropriate content, final design solution. }\end{array}$ \\
\hline & $\begin{array}{l}\text { Visuals and delivery (10\%) } \\
\text { Quality of portfolio presentation. Quality of visuals, images, } \\
\text { tables, and so on. Professional layout and format. }\end{array}$ \\
\hline \multirow{5}{*}{$\begin{array}{l}\text { Design Phase } \\
\text { and Outcome } \\
\text { (55\%) }\end{array}$} & $\begin{array}{l}\text { Understanding of design problems ( } 5 \%) \\
\text { Contextual framing of the project, responding to the design } \\
\text { brief. }\end{array}$ \\
\hline & $\begin{array}{l}\text { Background research and requirement analysis (10\%) } \\
\text { Identification of design background, areas and requirements. }\end{array}$ \\
\hline & $\begin{array}{l}\text { Demonstration of design process (5\%) } \\
\text { Quality of design and development processes, design } \\
\text { iterations, gradual resolution towards fully-specified design, } \\
\text { user testing and feedback. }\end{array}$ \\
\hline & $\begin{array}{l}\text { Concept generation, selection and demonstration (20\%) } \\
\text { Effective use of idea generation and selection methods, } \\
\text { diversity of solutions, concept evaluation and decision making. } \\
\text { Demonstrating the theory and rational underpinning them, } \\
\text { consideration of context of use, human factors, satisfaction of } \\
\text { user needs, creativity. }\end{array}$ \\
\hline & $\begin{array}{l}\text { Demonstration of engineering knowledge (15\%) } \\
\text { Consideration of engineering aspects, feasibility, structural } \\
\text { analysis, mechanism, material selection, manufacturability, } \\
\text { assembly, durability, reliability, risk consideration. }\end{array}$ \\
\hline $\begin{array}{l}\text { Presentations } \\
\text { of Design } \\
(25 \%)\end{array}$ & $\begin{array}{l}\text { Sketches, drawings, and prototype (25\%) } \\
\text { Effective use of sketches, storyboarding, mock-ups, CAD } \\
\text { drawings, visualisation and language, aesthetics throughout } \\
\text { the portfolio. The quality of your final prototype: evidence of } \\
\text { consideration of context of use, aesthetics, styling, and } \\
\text { consideration of engineering calculations and drawings, } \\
\text { functionality. }\end{array}$ \\
\hline
\end{tabular}

(b)

Fig. 1 Marking criteria and items of the marking rubrics used for assessing cohort $A$ (a) and cohort B (b) 
Besides, a 5\% marking weighting was deducted from the marking item 'sketches, drawings and prototypes' in the 'presentations of design' criterion and added to the item 'demonstration of engineering knowledge' in the 'design phase and outcome' criterion regarding the marking rubric for cohort $B$. The two marking rubrics used to assess cohort $A$ and $B$ were almost identical, despite the two slight changes. Therefore, it is considered that the changes made in the marking rubrics have zero to minimal impacts on students' learning. In addition, creativity, as well as other related terms, such as idea generation, idea evaluation and selection, were only mentioned in marking items 'demonstration of concepts' and 'concept generation and selection' in the marking rubric for cohort $A$ and 'concept generation, selection and demonstration' for cohort $B$. Therefore, creativity was not a direct driving force for learning perceived by students from both cohorts.

Creative Product Semantic Scale (CPSS), proposed by O'Quin and Besemer (1989), is a creativity assessment method for measuring products. This assessment method has been validated several times (Chulvi et al., 2012). Chulvi et al. (2012) defended the use of an adapted version of CPSS focusing on novelty and resolution (usefulness). These two criteria, novelty and usefulness, are also claimed as the key elements of design creativity (Sarkar \& Chakrabarti, 2008). Thereby, this adapted version of CPSS, as shown in Fig. 2, is employed in this study to measure the creativity of the designs produced by the students.

As shown in the figure, the adapted version of CPSS involves 18 bipolar pairs of items, of which 8 pairs refer to novelty (the rows in grey shadings) and 10 pairs indicate usefulness. Please note that the grey shadings are only shown here to provide the readers with a better understanding of the creativity assessment method used, while no shadings are used in the case study. Each bipolar pair of items is assessed using a seven-point Likert scale ranging from ' 1 ' to ' 7 '. The novelty score of a design is calculated based on the 8 pairs of novelty items, and the usefulness score is calculated according to the ten pairs of

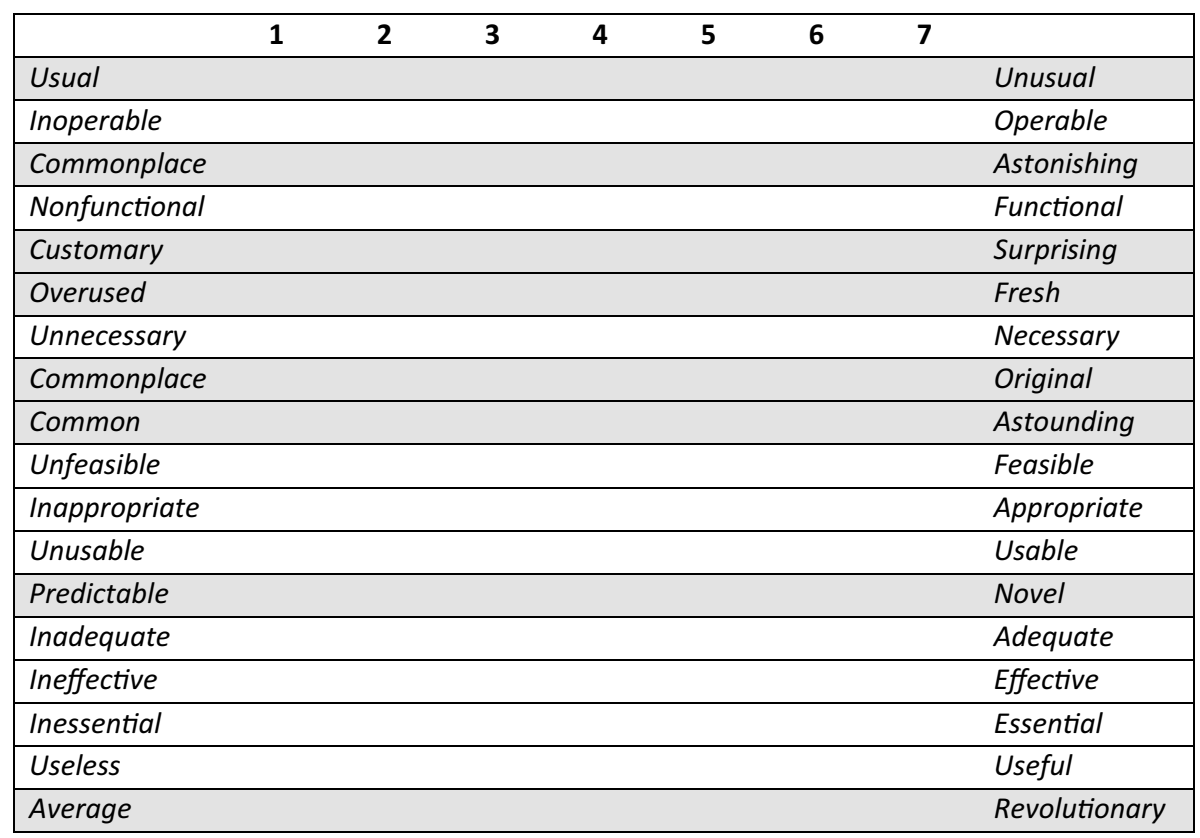

Fig. 2 The adapted version of the CPSS used in the study (Chulvi et al., 2012) 
usefulness items. The overall creativity is produced by adding up the 18 pairs of novelty and usefulness items. Thereby the maximum scores of novelty, usefulness and overall creativity are 56, 70 and 126, respectively.

Assessing design concepts is often led by experts, as it is a complex multi-criteria decision-making process (Zhai et al., 2009). Expert assessment has been used in a number of design studies for evaluating creativity, such as the ones conducted by Han et al. (2018c) and Sarkar and Chakrabarti (2011). Expert assessment is thereby employed in this study to measure the creativity of the final designs, by employing the adapted version of Creative Product Semantic Scale (CPSS).

\section{Implementation}

The case study has been performed in the project-based product development module led and taught by the principal author. Project-based learning is commonly used in design education that engages students in learning, and has a positive impact on enhancing students' creativity (Hanif et al., 2019; Lee, 2009). The module aims to teach intermediate elements of new product design and development, reinforce the role designers play in the development of new or existing products, and further develop students' drawing, graphical, presentation and design communication skills. The module requires students to design and develop a new consumer product through comprehending a given design problem, conducting user research, generating and selecting ideas, and developing the ideas into final design products. As a STEM design module, it also requires students to conduct engineering analysis, such as material and manufacturing considerations.

The two cohorts of students, cohort $A$ and $\operatorname{cohort} B$ (including $B *$ ), were given the same amount of time, 12 weeks, to accomplish their design projects and submit their assignments in the format of design portfolios. Before comparing the manual juicer designs produced by cohort $A$ and $B^{*}$ regarding creativity, it is necessary to ensure that both cohorts are at a similar intellectual level (knowledge and skills). The module teacher re-marked the 8 group work portfolios produced by cohort $A(\mathrm{~N}=8)$, simultaneously while marking the individual portfolios of cohort $B$, including cohort $B^{*}(\mathrm{~N}=15)$, using the same marking rubric (the one for cohort $B$ ) and employing the same marking standard. This could also eliminate the effects on marking caused by the time elapsed and the slight changes in the marking rubrics.

Cohort $A$ achieved an average grade of 66.34 out of 100 , with a median (Mdn) value of 67.50 and a median absolute deviation (MAD) value of 1.50 , while cohort $B^{*}$ achieved an average grade of $65.67(\mathrm{Mdn}=6.00, \mathrm{MAD}=2.00)$. A Mann-Whitney $U$ test is conducted to measure the statistical differences between the assignment grades of cohort $A$ and $B^{*}$. It indicates that cohort $A$ and cohort $B^{*}$ are not significantly different in terms of their assignment grades, $U=55.50, Z=-0.29, p=0.77, r=0.06$. This shows that cohort $A$ and $B^{*}$ possess similar intellectual abilities, including knowledge and skills, for a fair comparison.

The degree of creativity of the final designs produced by cohort $A$ and cohort $B^{*}$ are then assessed to yield practical results for examining the three hypotheses proposed. Six design experts with an average of 9.17 years $(\mathrm{SD}=4.41$ years) of design experience participated in this case study voluntarily, and signed up with standard case study protocols to not disclose the data used in the case study. The six design experts were asked to assess the 23 final design individually using the adapted version of CPSS. Before the design experts started the formal creativity assessment, short briefing and training sessions were provided. In order to avoid distracting the six design experts from focusing on the 23 final designs 
in the portfolios produced by the 8 groups in cohort $A$ and 15 individuals in cohort $B^{*}$, the final designs, involving the presentation of design, the context of use and engineering considerations, were extracted from the portfolios. The 23 final designs were collected and then mixed for creativity assessment to avoid evaluation bias and enhance reliability. Examples of the extracted final designs, one from cohort $A$ and one from cohort $B^{*}$, are shown in Fig. 3. The two examples attracted assignment grades of 68 and 69, respectively.

A Cronbach's alpha test is then conducted to measure the internal consistency of the assessment results among the six design experts. The test is conducted based on the CPSS bipolar pairs of items of the 8 group work designs produced by cohort $A$, and the 15 individual work designs produced by cohort $B^{*}$. Each expert assessed 23 designs in total, with 18 CPSS bipolar pairs of items per design. The Cronbach's alpha value $\alpha=0.66$, which indicates an acceptable level of internal consistency as a convention (Ursachi et al., 2015). This shows that the reliability of the expert evaluation is acceptable.

\section{Results}

The mean values of novelty, usefulness and overall creativity scores of the designs, produced by cohort $A$ (Design 1-8) and $B^{*}$ (Design 9-23), rated by the six design experts are calculated and employed for further analysis, as shown in Table 2 and 3, respectively. For example, in Table 2, Design 1 has attracted a mean creativity score of 61.83

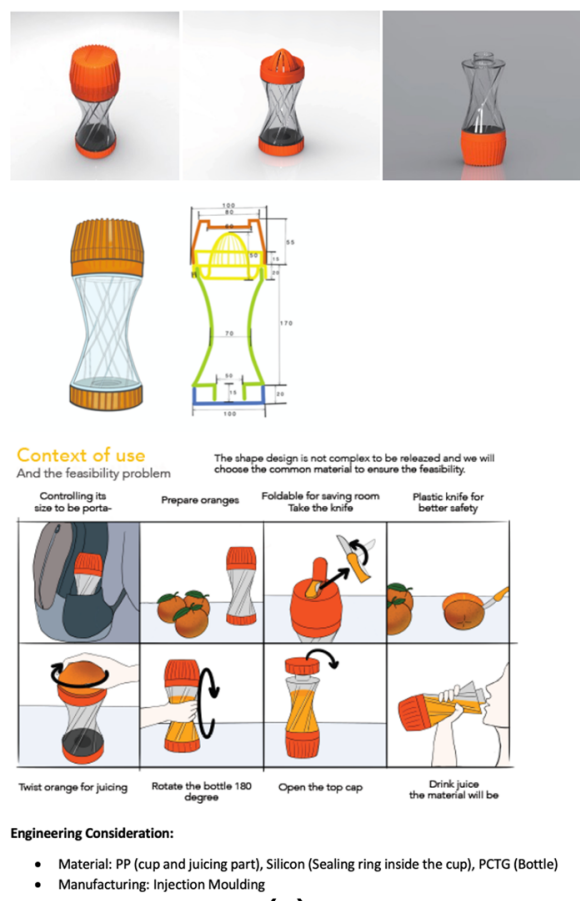

(a)
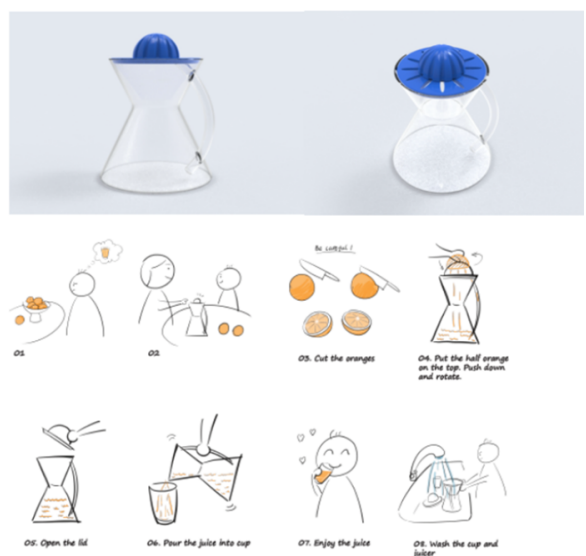

Engineering Consideration:

- Material: PLA

- Manufacturing: Injection Moulding

(b)

Fig. 3 Examples of final designs extracted from students' portfolios: (a). An example from cohort $A$ (assignment grade 68); (b). An example from cohort $B^{*}$ (assignment grade 69) 
Table 2 Mean scores of the 8 final designs produced by cohort $A$ rated by the six experts

\begin{tabular}{llll}
\hline & Mean novelty (Mdn, MAD) & Mean usefulness (Mdn, MAD) & Mean creativity (Mdn, MAD) \\
\hline Design 1 & $35.67(38.00,3.50)$ & $26.17(27.00,6.00)$ & $61.83(62.50,4.00)$ \\
Design 2 & $25.17(23.00,5.50)$ & $48.83(50.50,4.00)$ & $74.00(74.50,12.00)$ \\
Design 3 & $26.17(29.50,8.00)$ & $49.67(49.00,7.50)$ & $75.50(73.50,7.50)$ \\
Design 4 & $43.50(43.00,1.50)$ & $51.00(55.00,6.00)$ & $94.50(99.50,4.50)$ \\
Design 5 & $28.33(30.00,6.00)$ & $38.00(35.50,9.50)$ & $66.33(66.50,6.00)$ \\
Design 6 & $35.50(35.00,5.00)$ & $55.67(57.50,5.00)$ & $91.17(95.00,7.50)$ \\
Design 7 & $42.17(49.00,1.50)$ & $34.50(34.00,6.00)$ & $76.67(80.50,6.50)$ \\
Design 8 & $41.67(43.00,4.00)$ & $53.17(51.50,5.00)$ & $94.83(97.00,6.00)$ \\
Mean & $34.77(35.58,6.92)$ & $44.63(49.25,5.17)$ & $79.35(76.08,12.00)$ \\
\hline
\end{tabular}

Table 3 Mean scores of the 15 final designs produced by cohort $B *$ rated by the six experts

\begin{tabular}{llll}
\hline & Mean Novelty (Mdn, MAD) & Mean Usefulness (Mdn, MAD) & Mean Creativity (Mdn, MAD) \\
\hline Design 9 & $30.83(32.00,7.50)$ & $45.67(45.00,9.00)$ & $76.50(77.00,10.00)$ \\
Design 10 & $27.83(28.00,7.50)$ & $51.17(51.50,3.50)$ & $79.00(80.00,1.50)$ \\
Design 11 & $28.33(31.00,10.50)$ & $37.67(33.50,10.00)$ & $66.00(62.50,5.50)$ \\
Design 12 & $33.00(39.00,2.50)$ & $42.33(39.00,7.50)$ & $75.33(73.00,5.00)$ \\
Design 13 & $37.33(42.00,6.00)$ & $38.17(34.50,6.50)$ & $75.50(73.00,15.00)$ \\
Design 14 & $21.83(24.50,7.50)$ & $44.67(47.50,2.50)$ & $66.50(66.50,11.00)$ \\
Design 15 & $29.00(30.00,4.00)$ & $35.17(36.50,3.50)$ & $64.17(67.00,10.00)$ \\
Design 16 & $28.00(28.50,5.00)$ & $35.33(34.00,10.00)$ & $63.33(60.00,11.50)$ \\
Design 17 & $20.83(22.00,6.50)$ & $52.83(51.00,4.00)$ & $73.67(71.00,2.00)$ \\
Design 18 & $38.00(39.50,3.50)$ & $48.33(50.00,7.50)$ & $86.33(91.50,10.00)$ \\
Design 19 & $27.67(28.00,3.50)$ & $46.83(44.00,1.50)$ & $74.50(73.00,3.50)$ \\
Design 20 & $26.17(25.50,6.50)$ & $40.33(41.00,3.50)$ & $66.50(67.50,7.50)$ \\
Design 21 & $32.83(38.00,2.50)$ & $52.83(55.00,3.00)$ & $85.67(90.50,8.00)$ \\
Design 22 & $29.33(29.00,7.00)$ & $45.83(47.00,4.50)$ & $75.17(71.00,9.00)$ \\
Design 23 & $32.33(30.50,7.00)$ & $32.17(32.50,12.00)$ & $64.50(63.00,6.00)$ \\
Mean & $29.56(29.00,2.83)$ & $43.29(44.67,6.50)$ & $72.84(74.50,8.00)$ \\
\hline
\end{tabular}

with a median (Mdn) of 62.50 and a median absolute deviation (MAD) of 4.00, while its mean novel and usefulness scores are $35.67(\mathrm{Mdn}=38.00, \mathrm{MAD}=3.50)$ and 26.17 $(\mathrm{Mdn}=27.00, \mathrm{MAD}=6.00)$, respectively.

A Mann-Whitney $U$ test is conducted to measure the statistical differences between the mean novelty, usefulness and overall creativity scores of cohort $A(\mathrm{~N}=8)$ and $B^{*}(\mathrm{~N}=15)$, respectively. The mean novelty score of cohort $A, 34.77(\mathrm{Mdn}=35.58$, $\mathrm{MAD}=6.92)$, is higher than that of cohort $B^{*}, 29.56(\mathrm{Mdn}=29.00, \mathrm{MAD}=2.83)$, as shown in Table 2 and 3. However, the Mann-Whitney $U$ test shows that there are no statistically significant differences between the novelty scores of cohort $A$ and cohort $B^{*}$ with medium effect size, $U=38.00, Z=-1.42, p=0.155, r=0.30$. This shows that group work did not perform better than individual work in delivering novel design outputs in the product development module, which is against Hypothesis 1. 
Cohort $A$ has achieved a mean usefulness score of $44.63(\mathrm{Mdn}=49.25, \mathrm{MAD}=5.17)$, while cohort $B^{*}$ has achieved $43.29(\mathrm{Mdn}=44.67, \mathrm{MAD}=6.50)$. Although the mean usefulness scores are at a similar level, the statistical results indicate that the usefulness scores of cohort $A$ and cohort $B^{*}$ have shown no significant differences with small effect size, $U=49.00, Z=-0.71, p=0.478, r=0.15$. This implies that group work did not outperform individual work in terms of the usefulness of the outputs, which does not comply with Hypothesis 2.

The mean overall creativity scores of cohort $A$ and $B^{*}$ are 79.35 ( $\mathrm{Mdn}=76.08$, $\mathrm{MAD}=12.00)$ and $72.84(\mathrm{Mdn}=74.50, \mathrm{MAD}=8.00)$, respectively. Despite that the overall creativity score of cohort $A$ is higher in comparison with $\operatorname{cohort} B^{*}$, there are also no statistically significant differences between cohort $A$ and cohort $B^{*}$ with small effect size, $U=41.50, Z=-1.20, p=0.232, r=0.25$. This indicates that group work did not perform better than individual work regarding the overall creativity of the design outputs, which does not follow Hypothesis 3.

Further analysis is conducted to provide more insights by exploring the relationships between the novelty, usefulness, creativity scores of the final designs and the assignment grades for both cohort $A$ and $B^{*}$. Please note that the novelty, usefulness, and creativity scores used are the mean scores rated by the six experts, as shown in Table 2 and 3, while the assignment grades were rated by the module teacher. As shown in Fig. 4, the scatter charts depict the relationships between assignment grades and novelty scores (a), assignment grades and usefulness scores (b), and assignment grades and creativity scores (c), for the 8 groups from cohort $A$ (the blue ' $\mathrm{x}$ ') and the 15 individuals from cohort $B^{*}$ (the orange ' $x$ ').

As shown in Fig. 4, there seems to be no clear relationships between the novelty, usefulness, creativity scores and the assignment grades for both cohorts, respectively. Therefore, Pearson correlation tests are performed to explore the relationships statistically, of which the results are shown in Table $4($ cohort $A)$ and Table 5 (cohort $\left.B^{*}\right)$. Only cohort $A$ has shown a medium correlation between novelty and assignment grade, while all other correlations of cohort $A$ and $B^{*}$ range from small to zero. However, there are no statistically significant correlations between novelty, usefulness, creativity and assignment grade for both cohorts, respectively. As a consequence, an assignment which has achieved a high grade does not necessarily indicate its final design would be highly novel, useful or creative.

\section{Discussion}

\section{Discussion of the case study}

As the module teacher and leader of the product development module, the principal author was required to change the module from employing group work in 2018/2019 academic year to individual work in 2019/2020 academic year according to the recommendations of an accreditation visit. This provided the opportunity for the authors to study how group work and individual work affect students in learning design knowledge, especially creativity.

Although many existing studies have emphasised the significance of employing group work in design education, the case study conducted has shown that group work and individual work have no significant differences in the final designs produced, in terms of novelty, usefulness, and overall creativity. Therefore, the empirical results of this study do not 
Assignment Grades and Novelty Scores

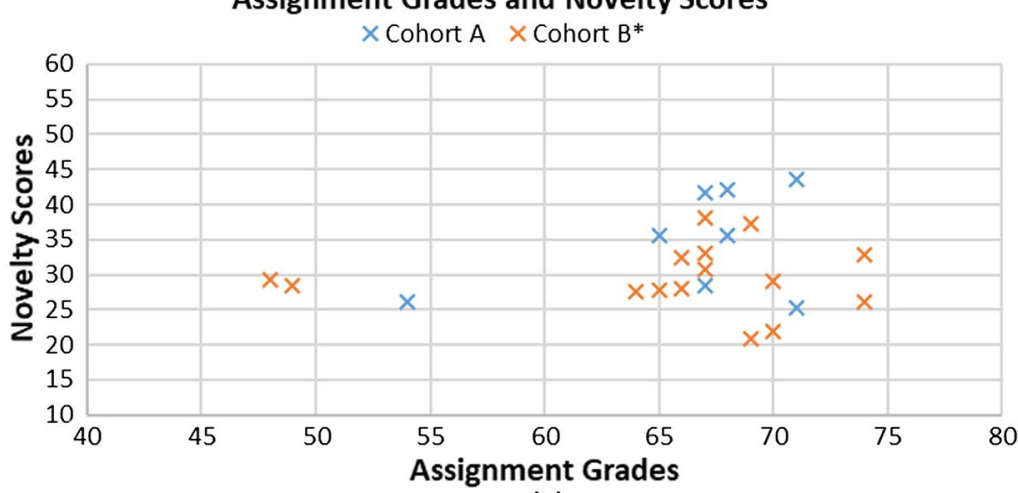

(a)

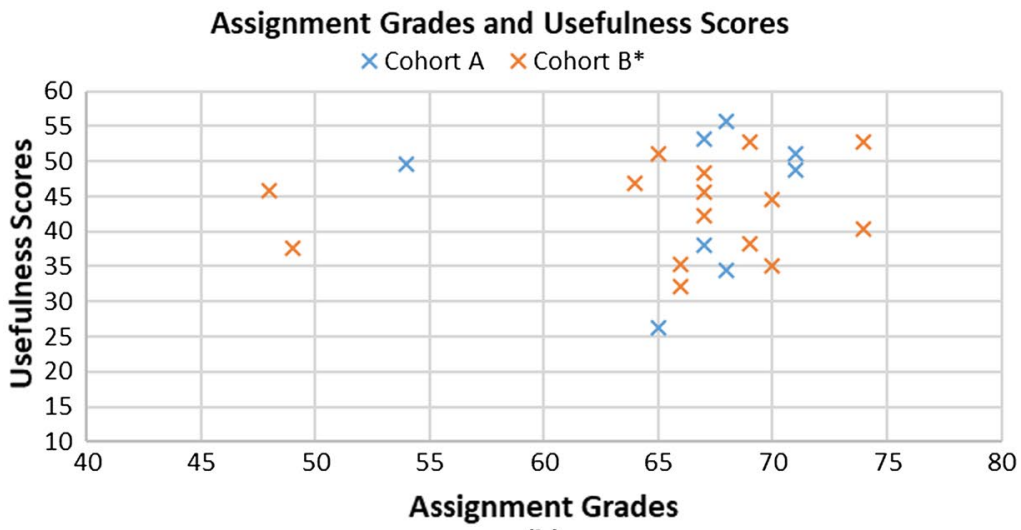

(b)

\section{Assignment Grades and Creativity Scores}

$\times$ Cohort A $\times$ Cohort B*

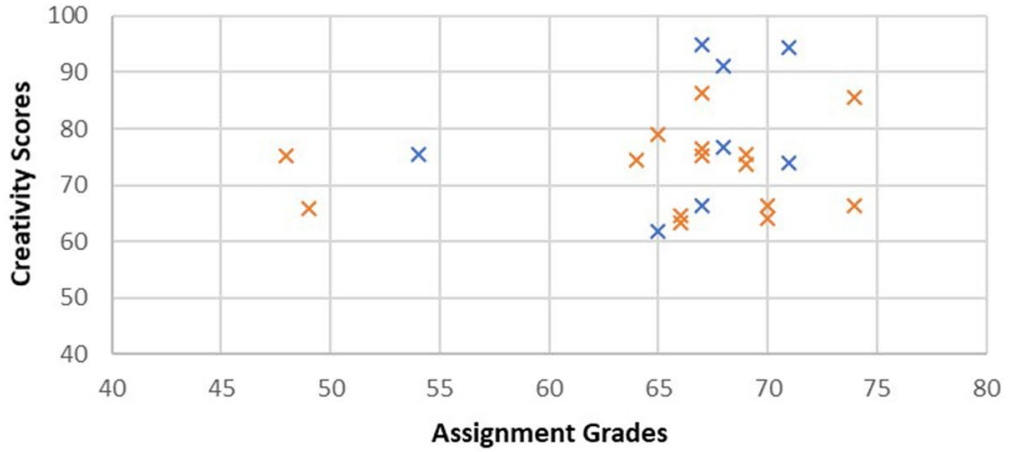

(c)

Fig. 4 Scatter charts showing the relationships between assignment grades and novelty scores (a), usefulness scores (b), and creativity scores (c) for cohort $A$ and $B^{*}$ 
Table 4 Pearson's Correlation of cohort A (group work)

\begin{tabular}{|c|c|c|c|c|c|c|}
\hline \multirow[t]{2}{*}{ Cohort A } & \multicolumn{2}{|c|}{ Novelty } & \multicolumn{2}{|c|}{ Usefulness } & \multicolumn{2}{|c|}{ Creativity } \\
\hline & $r$ & $p$ & $r$ & $p$ & $R$ & $p$ \\
\hline Assignment grade & .408 & .316 & .037 & .931 & .277 & .506 \\
\hline
\end{tabular}

Pearson's Correlation Coefficient $r: .1$ to $.3=$ small, .3 to $.5=$ medium, .5 to $1.0=$ large

$* p<0.05$

\begin{tabular}{|c|c|c|c|c|c|c|}
\hline \multirow[t]{2}{*}{ Cohort B* } & \multicolumn{2}{|c|}{ Novelty } & \multicolumn{2}{|c|}{ Usefulness } & \multicolumn{2}{|c|}{ Creativity } \\
\hline & $r$ & $p$ & $r$ & $p$ & $R$ & $p$ \\
\hline Assignment Grade & .013 & .963 & .114 & .685 & .110 & .696 \\
\hline
\end{tabular}

Pearson's Correlation Coefficient $r: .1$ to $.3=$ small, .3 to $.5=$ medium, .5 to $1.0=$ large

$* p<0.05$

support that group work is more beneficial for supporting students in producing creative design outputs in STEM design education in comparison with individual work. Further correlation analysis suggests that the level of creativity (including novelty, usefulness and overall creativity) of a final design is not related to its corresponding assignment's grade. In other words, there tends to be no relationships between a student's academic performance and creativity performance in the product development module. As a result, whether a student could produce a highly creative design is not significantly associated with the learning strategy used (group work or individual work) and even the student's academic performance, for the case study concerned.

Several factors could have caused these results. One of them could be the disadvantages of group work, such as peer pressure and the existence of dominant members, revealed by many researchers. These disadvantages might have affected the students, which employed group work, in learning and applying creativity knowledge and skills. For example, Wiltermuth (2009) showed that a dominant group member may influence other submissive members in contributing fewer ideas to group discussion. This leads to a reduction of the number and diversity of ideas produced by the group, which impairs the capability of the group in generating creative ideas. As a consequence, designs generated by employing group work and individual work could be at a similar creativity level. Therefore, if design educators are equipped with better understandings and management skills of group work (Davies, 2009; Woolard, 2018), there is a potential to better support groups of students in producing creative designs in the context of STEM design education.

Starkey et al. (2016) revealed that there is a reduction of creativity throughout the design process, as students often abandon novel concepts. It is suggested that individuals' definition of a 'good' idea affects the ideas they select (Johnson \& D'Lauro, 2018). For example, if a 'good' idea is defined as a novel and useful idea, then individuals might select ideas that are creative. Rietzschel et al. (2010) indicated that students prefer to select feasible and desirable ideas rather than novel ones after idea generation. Similarly, Toh and Miller $(2015,2016)$ demonstrated that groups that produce highly creative ideas do not necessarily select creative concepts, as students focus on feasibility and neglect creativity 
during the selection process, despite creativity being set as a design requirement. Thereby, students involved in this study might have selected ideas, which they believed would meet the requirements of the assignment, but not creative ones for further development. This could be another main reason underpinning the fact that the creativity of the final designs produced by group work (cohort $A$ ) and individual work (cohort $B^{*}$ ) are at a similar level, not relating to the assignment grades. Design creativity assessment methods should thereby be employed in design education, rather than merely using the existing idea evaluation and selection tools. This could support students in selecting creative ideas that are novel and useful, rather than desirable ideas perceived by the students.

Another factor might be that creativity was not considered a significant item in the marking rubrics used in the case study, as shown in Fig. 1. The rubrics were provided to the students from both cohorts during the 'week one-introduction' class of the module. Therefore, students might have spent more time on marking items which have higher weightings, such as 'sketches, drawings and prototypes', rather than creative activities, such as idea generation and evaluation, to achieve a better overall assignment grade. Thus, increasing the weightings of creativity related marking items has the potential to drive students to focus on creative design activities. This might result in highly creative outputs for both group and individual work.

However, the results of the case study might also be determined by the design project ' $\mathrm{a}$ new manual juicer design' employed in the module. A manual juicer is a classic product, with numerous existing ones on the market, which has rather stable and maturely defined functions in general. It might be challenging for students, even design experts, to come up with radically new and path-breaking manual juicers that are considered highly creative. Therefore, innovative design projects, such as 'a portable blender', could be employed in future studies to provide more insights.

In addition, design students (novices) think and work differently from expert practitioners. For example, design novices tend to use 'trial and error' to approach design tasks, while experts employ particular design strategies (Ahmed et al., 2003); design experts spend significantly more time on problem scoping and information gathering than design students during the design process (Atman et al., 2007); design experts prefer to use analogical reasoning for problem solving and identification, while novices lack such reasoning processes (Ahmed \& Christensen, 2009). It is also shown that the creativity of designs produced is closely related to the designer's knowledge of managing and monitoring the solution generating process (Christiaans \& Venselaar, 2005). In addition, design experts are often involved in designing complex systems and products, which requires cooperation and group work. Hence a driver for design experts to master group work skills. Therefore, group work could be a useful and effective approach to support the generation of creative design outputs for design experts, but might not be effective for design students.

\section{Education implications}

Group work offers a series of potential benefits and attractions in higher education, especially in delivering STEM design programmes. It can help students understand the nature of collaborative design processes, and fosters sought-after employability skills for future professional design activities ( $\mathrm{Qu}$ et al., 2019; Thompson, 2002). Furthermore, the use of group work could reduce the resources needed, such as staffing and marking effort (Almond, 2009; Pfaff \& Huddleston, 2003), as well as meet the requirements of design course accreditations (Dowlen, 2019). However, Kim et al. (2008) indicated that design 
team creativity is related to the personal creativity of team members. Individual work can help students cultivate independent thinking and decision-making abilities, as well as conducting work without depending on others with accompanying ease of assessment. For the case study concerned, both group work and individual work have their advantages and disadvantages, and do not show significant differences in generating creative design outputs. We thereby suggest a mixed-use of individual work and group work in design education to foster students with an extended range of skills and abilities, as well as provide different learning experience.

From the students' perspective, successful group work could be challenging, as it requires students to have self-efficacy beliefs to encourage each other to utilise resources effectively and engage in high-quality group discussions (Bandura, 2001; Chang \& Brickman, 2018; Wang \& Lin, 2007), and appropriate communication styles to organise group work and cooperate with one another in both monocultural and multicultural group settings (Marks et al., 2000; Popov et al., 2012). In order to achieve successful individual work, students need to have the ability to set their own objectives and monitor their own progress, the responsibility for their own studies, and the willingness to evaluate and reflect their own learnings (Hockings et al., 2018). In addition to the capabilities and skills required for group and individual work, students also have differences in their learning styles. Activist, reflector, pragmatist and theorist are the four basic learning styles (Mumford \& Honey, 1992), while each style might lead to different work preferences. For instance, activists prefer small group discussions and training others but disfavour self-reading, writing and thinking (Honey \& Mumford, 2000), so it might be expected that activists could perform better in group work than individual work. As a result, there is a need to consider all these differences among students in project work. Furthermore, Crilly and Moroşanu Firth (2019) indicated that the combination of group work and individual work have creative advantages. Therefore, integrated approaches that combine both individual and group work within a single project could also be employed by design educators.

Although creativity has been considered to play a significant role in STEM design education, more effort is needed in teaching design creativity to foster creative designers and design engineers. For instance, design educators could highlight the importance of creativity in their marking rubrics, by adding more weightings on creative design activities, such as idea generation and evaluation. In group work-based design projects, educators need to better manage the groups to avoid the negative impacts caused, which might impair the groups' creative abilities. The use of design creativity assessment methods in design education is also necessary for supporting students in delivering creative design outputs. However, design educators should employ creativity assessment methods that are suitable for students, such as the Comparative Creativity Assessment (CCA) and the Multi-Point Creativity Assessment (MPCA) (Oman et al., 2013), rather than expert oriented methods, such as Consensual Assessment Technique (CAT) (Amabile, 1982). In addition, design educators could also collaborate with design creativity researchers to come up with new tools, involving computational ones, to support design students in creative design activities, especially design creativity assessment.

\section{Limitations}

While this study compares group work and individual work in producing creative design outputs, there are a few limitations. First, the study involves 47 valid participants from two cohorts of students, 32 from the first cohort and 15 from the second cohort, studying the 
Industrial Design programme. The relatively low number of students has led to a limited number of assignments samples, with 8 group and 15 individual design portfolios from the first and second cohort, respectively. However, the programme was designed to accommodate such a small number of students in each cohort, due to the nature of the programme at the university. Therefore, a similar case study could be conducted within a STEM design programme that contains a large cohort size, or even at multiple universities around the world, to yield a more general and universal result.

Secondly, marking rubrics were used in the study as the instrument to assess the project assignments as a convention in the university, and to measure the intellectual abilities of the two cohorts for a fair comparison regarding their creativity performance in the product development module. However, rubrics have inherent weaknesses in terms of reliability and validity. Although the marking rubrics used cover a broad range of assessment criteria, the results obtained could be a function of the rubric chosen. One solution to this issue is to improve the clarity and appropriateness of the language used, which is suggested by Reddy and Andrade (2010), for enhancing the validity of the rubric. Another solution is to employ a different approach, such as comparative judgment and performance test, instead of using marking rubrics. Such approaches could provide more reliable and valid results (Pollitt, 2012) regarding the assessment of the students' knowledge and skills through their assignments.

Thirdly, certain aspects of the students' portfolios were removed, such as user research, idea generation and selection processes, for the creativity assessment to help the experts focus on evaluating the final designs which involve the presentation of design, the context of use and engineering considerations. However, this might have removed the insight into students' decision makings around novelty versus usefulness, which could have potentially obscured a level of authenticity and affected the assessments made. Therefore, the whole portfolio could be provided to experts for creativity assessments in future research. This would require the experts to affirm stronger commitments to the assessments, as creativity assessment is a multi-decision making process that is often time-consuming. Alternatively, another group of experts could be employed to analyse the students' whole design process to provide more insights on their creativity performance from the reality and complexity of designing and innovating.

\section{Conclusion}

This paper has explored the use of group and individual work in a STEM product development module, with a focus of the impacts on the generation of creative design outputs. Existing literature presents that group work is an often-used and effective learning strategy in design education. However, few studies have provided empirical evidence indicating group work outperforms individual work with regards to design creativity. A case study is thereby conducted to explore whether group work is more beneficial for design creativity education in comparison with individual work. The empirical results indicate that there are no significant differences between the design outputs generated by employing group work and individual work in terms of the novelty, usefulness and overall creativity, respectively. This shows that whether to employ group work or individual work in design education has little impact on fostering students in producing creative designs, based on the results of this study. Further explorations of the relationship between novelty, usefulness, creativity and 
assignment grade indicates that students' creativity performance is not related to their academic performance, for the case study concerned.

The outcomes of the research contribute to the body of knowledge in research on design creativity and design education, which provide evidence for how group work and individual work impact students' creative design outputs. It shows that employing group work and individual work do not affect students' creative outputs, while group and individual work have complementary advantages and disadvantages. Thereby, we suggest a mixed-use of group work and individual work, including the use of integrated approaches combining individual and group work, in STEM design education rather than using solely group work or individual work to support students in mastering design creativity knowledge and skills. In addition, it is also implied that design educators could modify marking rubrics and manage groups better to enhance students' creative outputs. Most importantly, student-oriented creativity assessment tools, either non-computational or computational ones, need to be explored and introduced in STEM design modules. The results of this study serve as an empirical basis for further research on design creativity and are used to indicate recommendations for instruction in STEM design education.

Authors' contributions Dr. JH: The research idea, research method, case study design, data analysis and writing the paper. Dr. DP: Case study design, data collection, proof reading, feedback. Dr. MH: Case study design, data collection, academic suggestions. Prof PRNC: Overall guidance, comments, proof reading, editing.

Open Access This article is licensed under a Creative Commons Attribution 4.0 International License, which permits use, sharing, adaptation, distribution and reproduction in any medium or format, as long as you give appropriate credit to the original author(s) and the source, provide a link to the Creative Commons licence, and indicate if changes were made. The images or other third party material in this article are included in the article's Creative Commons licence, unless indicated otherwise in a credit line to the material. If material is not included in the article's Creative Commons licence and your intended use is not permitted by statutory regulation or exceeds the permitted use, you will need to obtain permission directly from the copyright holder. To view a copy of this licence, visit http://creativecommons.org/licenses/by/4.0/.

\section{References}

Ahmed, S., \& Christensen, B. T. (2009). An in situ study of analogical reasoning in novice and experienced design engineers. Journal of Mechanical Design. https://doi.org/10.1115/1.3184693

Ahmed, S., Wallace, K. M., \& Blessing, L. T. (2003). Understanding the differences between how novice and experienced designers approach design tasks. Research in Engineering Design, 14, 1-11. https:// doi.org/10.1007/s00163-002-0023-z

Algashaam NM (2015) Teamwork vs. individual responsibility. International Journal of Scientific \& Engineering Research 6

Almond, R. J. (2009). Group assessment: Comparing group and individual undergraduate module marks. Assessment \& Evaluation in Higher Education, 34, 141-148. https://doi.org/10.1080/0260293080 1956083

Altshuller, G. S. (1984). Creativity as an exact science: The theory of the solution of inventive problems. Gordon and Breach Publishers.

Amabile, T. M. (1982). Social psychology of creativity: A consensual assessment technique. Journal of Personality and Social Psychology, 43, 997-1013. https://doi.org/10.1037/0022-3514.43.5.997

Amabile, T. M. (1983). The social psychology of creativity. Springer. 
Atman, C. J., Adams, R. S., Cardella, M. E., Turns, J., Mosborg, S., \& Saleem, J. (2007). Engineering design processes: A comparison of students and expert practitioners. Journal of Engineering Education, 96, 359-379. https://doi.org/10.1002/j.2168-9830.2007.tb00945.x

Bacon, D. R. (2005). The effect of group projects on content-related learning. Journal of Management Education, 29, 248-267. https://doi.org/10.1177/1052562904263729

Bandura, A. (2001). Social cognitive theory: An agentic perspective. Annual Review of Psychology, 52, 1-26. https://doi.org/10.1146/annurev.psych.52.1.1

Beebe SA, Masterson JT (2003) Communicating in small groups, Boston, MA

Bissola, R., \& Imperatori, B. (2011). Organizing individual and collective creativity: Flying in the face of creativity clichés. Creativity and Innovation Management, 20, 77-89. https://doi.org/10.1111/j.14678691.2011.00597.x

Boud, D., Cohen, R., \& Sampson, J. (1999). Peer learning and assessment. Assessment \& Evaluation in Higher Education, 24, 413-426. https://doi.org/10.1080/0260293990240405

Bozkurt Altan, E., \& Tan, S. (2020). Concepts of creativity in design based learning in STEM education. International Journal of Technology and Design Education. https://doi.org/10.1007/ s10798-020-09569-y

Bruton, D. (2011). Learning creativity and design for innovation. International Journal of Technology and Design Education, 21, 321-333. https://doi.org/10.1007/s10798-010-9122-8

Burke, A. (2011). Group work: How to use groups effectively. Journal of Effective Teaching, 11, 87-95.

Buzan T (2006) Mind mapping. Pearson Education.

Chakrabarti, A., \& Shu, L. H. (2010). Biologically inspired design. Artificial Intelligence for Engineering Design, Analysis and Manufacturing, 24, 453-454. https://doi.org/10.1017/S0890060410000326

Chang Y, Brickman P (2018) When group work doesn't work: insights from students. CBE-Life Sciences Education 17:ar52. https://doi.org/10.1187/cbe.17-09-0199

Childs, P. R. N. (2018). Mechanical design engineering handbook (2nd ed.). Butterworth-Heinemann.

Childs P, Fountain R (2011) Commercivity. In: Paper presented at the DS 69: proceedings of E\&PDE 2011, the 13th international conference on engineering and Product Design Education, London, UK, 08.-09.09.2011

Childs PRN, Hamilton T, Morris RD, Johnston G (2006) Centre for technology enabled creativity. In: Paper presented at the DS 38: Proceedings of E\&DPE 2006, the 8th International Conference on Engineering and Product Design Education, Salzburg, Austria, 07.-08.09.2006,

Chiu, I., \& Shu, L. H. (2012). Investigating effects of oppositely related semantic stimuli on design concept creativity. Journal of Engineering Design, 23, 271-296. https://doi.org/10.1080/09544828.2011. 603298

Christiaans, H., \& Venselaar, K. (2005). Creativity in design engineering and the role of knowledge: Modelling the expert. International Journal of Technology and Design Education, 15, 217-236. https://doi. org/10.1007/s10798-004-1904-4

Chulvi, V., Sonseca, Á., Mulet, E., \& Chakrabarti, A. (2012). Assessment of the relationships among design methods, design activities, and creativity. Journal of Mechanical Design, 134, 111004-111004111011. https://doi.org/10.1115/1.4007362

Court, A. W. (1998). Improving creativity in engineering design education. European Journal of Engineering Education, 23, 141-154. https://doi.org/10.1080/03043799808923493

Crilly, N., \& Moroşanu Firth, R. (2019). Creativity and fixation in the real world: Three case studies of invention, design and innovation. Design Studies, 64, 169-212. https://doi.org/10.1016/j.destud.2019. 07.003

Cronin, M., \& McCabe, A. (2017). The benefits of individual versus group work in a biology based laboratory setting. International Journal of Research Studies in Education, 7, 65-76.

Cropley, D. H. (2015). Promoting creativity and innovation in engineering education. Psychology of Aesthetics, Creativity, and the Arts, 9, 161.

Cropley, D., \& Cropley, A. (2010). Recognizing and fostering creativity in technological design education. International Journal of Technology and Design Education, 20, 345-358. https://doi.org/10.1007/ s10798-009-9089-5

Cropley, D. H., Kaufman, J. C., \& Cropley, A. J. (2011). Measuring creativity for innovation management. Journal of Technology Management \& Innovation, 6, 13-30.

Cross, N. (2011). Design thinking: Understanding how designers think and work. Berg Publishers.

Daly SR, McKilligan S, Leahy K, Seifert CM (2019) Teaching design innovation skills: design heuristics support creating, developing, and combining ideas. In: Schaefer D, Coates G, Eckert C (eds) Design education today: technical contexts, programs and best practices. Springer, Cham, pp 37-60. . https:// doi.org/10.1007/978-3-030-17134-6_3 
Davies, W. M. (2009). Groupwork as a form of assessment: Common problems and recommended solutions. Higher Education, 58, 563-584. https://doi.org/10.1007/s10734-009-9216-y

De Bono, E. (1985). Six thinking hats. Penguin.

De Bono, E. (2010). Lateral thinking: A textbook of creativity. Penguin.

Demirkan, H., \& Afacan, Y. (2012). Assessing creativity in design education: Analysis of creativity factors in the first-year design studio. Design Studies, 33, 262-278. https://doi.org/10.1016/j.destud.2011.11. 005

Dowlen C (2019) Accreditation of Design Education Programmes. In: Schaefer D, Coates G, Eckert C (eds) Design education today: technical contexts, programs and best practices. Springer, Cham, pp 293324. https://doi.org/10.1007/978-3-030-17134-6_13

Eberle, B. (1996). Scamper: Games for imagination development. Prufrock Press.

Ehrlenspiel, K., Giapoulis, A., \& Günther, J. (1997). Teamwork and design methodology-Observations about teamwork in design education. Research in Engineering Design, 9, 61-69. https://doi.org/10. 1007/BF01596482

Elliott, N., \& Higgins, A. (2005). Self and peer assessment - does it make a difference to student group work? Nurse Education in Practice, 5, 40-48. https://doi.org/10.1016/j.nepr.2004.03.004

Faure, C. (2004). Beyond brainstorming: Effects of different group procedures on selection of ideas and satisfaction with the process. The Journal of Creative Behavior, 38, 13-34. https://doi.org/10.1002/j. 2162-6057.2004.tb01229.x

Fernández Dobao, A. (2012). Collaborative writing tasks in the L2 classroom: Comparing group, pair, and individual work. Journal of Second Language Writing, 21, 40-58. https://doi.org/10.1016/j.jslw.2011. 12.002

Georgiev, G. V., \& Casakin, H. (2019). Semantic measures for enhancing creativity in design education. Proceedings of the Design Society: International Conference on Engineering Design, 1, 369-378. https://doi.org/10.1017/dsi.2019.40

Gero, J., Yu, R., \& Wells, J. (2019). The effect of design education on creative design cognition of high school students. International Journal of Design Creativity and Innovation, 7, 196-212. https://doi. org/10.1080/21650349.2019.1628664

Girotra, K., Terwiesch, C., \& Ulrich, K. T. (2010). Idea generation and the quality of the best idea. Management Science, 56, 591-605.

Goldschmidt, G., \& Tatsa, D. (2005). How good are good ideas? Correlates of design creativity. Design Studies, 26, 593-611. https://doi.org/10.1016/j.destud.2005.02.004

Gray, C. M., McKilligan, S., Daly, S. R., Seifert, C. M., \& Gonzalez, R. (2019). Using creative exhaustion to foster idea generation. International Journal of Technology and Design Education, 29, 177-195. https://doi.org/10.1007/s10798-017-9435-y

Guo, J., Su, Q., \& Zhang, Q. (2017). Individual creativity during the ideation phase of product innovation: An interactional perspective. Creativity and Innovation Management, 26, 31-48. https://doi. org/10.1111/caim.12205

Gupta, M. L. (2004). Enhancing student performance through cooperative learning in physical sciences. Assessment \& Evaluation in Higher Education, 29, 63-73. https://doi.org/10.1080/0260293032 000158162

Han, J., Forbes, H., \& Schaefer, D. (2021). An exploration of how creativity, functionality, and aesthetics are related in design. Research in Engineering Design, 32, 289-307. https://doi.org/10.1007/ s00163-021-00366-9

Han, J., Shi, F., Chen, L., \& Childs, P. R. N. (2018a). The Combinator - a computer-based tool for creative idea generation based on a simulation approach. Design Science, 4, e11. https://doi.org/10. 1017/dsj.2018.7

Han, J., Shi, F., Chen, L., \& Childs, P. R. N. (2018b). A computational tool for creative idea generation based on analogical reasoning and ontology. Artificial Intelligence for Engineering Design, Analysis and Manufacturing, 32, 462-477. https://doi.org/10.1017/S0890060418000082

Han J, Shi F, Park D, Chen L, Childs P The conceptual distances between ideas in combinational creativity. In: DS92: Proceedings of the DESIGN 2018 15th International Design Conference, $2018 \mathrm{c}$. pp 1857-1866. . https://doi.org/10.21278/idc.2018.0264

Hanif, S., Wijaya, A. F. C., \& Winarno, N. (2019). Enhancing students' creativity through STEM project-based learning. Journal of Science Learning, 2, 50-57.

Harris, J. S. (1976). New product profile chart. ChemTech, 6, 554-564.

He, Y., \& Luo, J. (2017). The novelty 'sweet spot' of invention. Design Science, 3, e21. https://doi.org/ $10.1017 / \mathrm{dsj} .2017 .23$

Helms, M., Vattam, S. S., \& Goel, A. K. (2009). Biologically inspired design: Process and products. Design Studies, 30, 606-622. https://doi.org/10.1016/j.destud.2009.04.003 
Hernandez NV, Schmidt LC, Kremer GO, Lin C-Y An empirical study of the effectiveness of selected cognitive aids on multiple design tasks. In, Dordrecht, 2014. Design Computing and Cognition '12. Springer, pp 227-246

Hockings, C., Thomas, L., Ottaway, J., \& Jones, R. (2018). Independent learning - What we do when you're not there. Teaching in Higher Education, 23, 145-161. https://doi.org/10.1080/13562517. 2017.1332031

Honey, P., \& Mumford, A. (2000). The learning styles helper's guide. Peter Honey Publications Ltd.

Howard, T. J., Culley, S., \& Dekoninck, E. A. (2011). Reuse of ideas and concepts for creative stimuli in engineering design. Journal of Engineering Design, 22, 565-581. https://doi.org/10.1080/09544 821003598573

Howard-Jones, P. A. (2002). A Dual-state model of creative cognition for supporting strategies that foster creativity in the classroom. International Journal of Technology and Design Education, 12, 215. https://doi.org/10.1023/A:1020243429353

Johnson, B. R., \& D'Lauro, C. J. (2018). After brainstorming, groups select an early generated idea as their best idea. Small Group Research, 49, 177-194. https://doi.org/10.1177/1046496417720285

Kennedy, G. J. (2005). Peer-assessment in group projects: Is it worth it? In Proceedings of the 7th Australasian conference on Computing education-Volume 42. Citeseer (pp. 59-65)

Kim, Y. S., Kim, M. S., \& Wilde, D. J. (2008). Toward the management of design creativity: Personal creativity modes, design activity, and team interaction. Design Management Journal, 3, 45-52. https://doi.org/10.1111/j.1948-7177.2008.tb00013.x

Kind, P. M., \& Kind, V. (2007). Creativity in science education: Perspectives and challenges for developing school science. Studies in Science Education, 43, 1-37. https://doi.org/10.1080/0305726070 8560225

King, P. E., \& Behnke, R. R. (2005). Problems associated with evaluating student performance in groups. College Teaching, 53, 57-61. https://doi.org/10.3200/CTCH.53.2.57-61

Kirschner, P. A. (2001). Using integrated electronic environments for collaborative teaching/learning. Learning and Instruction, 10, 1-9. https://doi.org/10.1016/S0959-4752(00)00021-9

Kohn, N. W., Paulus, P. B., \& Choi, Y. (2011). Building on the ideas of others: An examination of the idea combination process. Journal of Experimental Social Psychology, 47, 554-561. https://doi. org/10.1016/j.jesp.2011.01.004

Kornish, L. J., \& Ulrich, K. T. (2014). The importance of the raw idea in innovation: Testing the sow's ear hypothesis. Journal of Marketing Research, 51, 14-26. https://doi.org/10.1509/jmr.12.0401

Koronis, G., Chia, P. Z., Kang Kai Siang, J., Silva, A., Yogiaman, C., \& Raghunath, N. (2019). An empirical study on the impact of design brief information on the creativity of design outcomes with consideration of gender and gender diversity. Journal of Mechanical Design. https://doi.org/ $10.1115 / 1.4043207$

Larkin TL (2015) creativity in STEM education: reshaping the creative project. In: 2015 international conference on interactive collaborative learning (ICL), 20-24 (pp 1184-1189). https://doi.org/10. 1109/ICL.2015.7318203

Lee, J. H., Ostwald, M. J., \& Gu, N. (2017). Cognitive challenges for teamwork in design. In T. Richard (Ed.), Collaboration and student engagement in design education (pp. 55-75). IGI Global. https:// doi.org/10.4018/978-1-5225-0726-0.ch003

Lee, N. (2009). Project methods as the vehicle for learning in undergraduate design education: a typology. Design Studies, 30, 541-560. https://doi.org/10.1016/j.destud.2009.03.002

Li, Y., Schoenfeld, A. H., diSessa, A. A., Graesser, A. C., Benson, L. C., English, L. D., \& Duschl, R. A. (2019). On thinking and STEM education. Journal for STEM Education Research, 2, 1-13. https://doi.org/10.1007/s41979-019-00014-x

Lin, J.-W., Tsai, C.-W., Hsu, C.-C., \& Chang, L.-C. (2019). Peer assessment with group awareness tools and effects on project-based learning. Interactive Learning Environments. https://doi.org/10.1080/ 10494820.2019 .1593198

Lin, S.-F. (2019). Students' attitudes towards learning english vocabulary through collaborative group work versus individual work. Journal of Education and Learning, 8, 93-111.

Linsey, J. S., Clauss, E. F., Kurtoglu, T., Murphy, J. T., Wood, K. L., \& Markman, A. B. (2011). An experimental study of group idea generation techniques: Understanding the roles of idea representation and viewing methods. Journal of Mechanical Design. https://doi.org/10.1115/1.4003498

Linsey, J. S., Green, M. G., Murphy, J. T., Wood, K. L., \& Markman, A. B. (2005). "Collaborating To Success": an experimental study of group idea generation techniques. In ASME 2005 international design engineering technical conferences and computers and information in engineering conference (pp 277-290). https://doi.org/10.1115/detc2005-85351 
Lu, C.-C. (2017). Interactive effects of environmental experience and innovative cognitive style on student creativity in product design. International Journal of Technology and Design Education, 27, 577-594. https://doi.org/10.1007/s10798-016-9368-X

Luo, J., Sarica, S., Wood, K. L. (2019). Computer-aided design ideation using InnoGPS. In ASME 2019 international design engineering technical conferences and computers and information in engineering conference. V02AT03A011. . https://doi.org/10.1115/detc2019-97587

Marks, M. A., Zaccaro, S. J., \& Mathieu, J. E. (2000). Performance implications of leader briefings and team-interaction training for team adaptation to novel environments. Journal of Applied Psychology, 85, 971-986. https://doi.org/10.1037/0021-9010.85.6.971

Mattioli F. (2019). Cross-cultural design teamwork: researching at the edge between design and crosscultural management. In IASDR conference 2019-design revolutions (pp 1-7)

Mbalamula YS (2018) Effect of group versus individual assessments on coursework among undergraduates in Tanzania: implications for continuous assessments in universities. Pedagogical Research 3:n1

McMahon, K., Ruggeri, A., Kämmer, J. E., \& Katsikopoulos, K. V. (2016). Beyond idea generation: The power of groups in developing ideas. Creativity Research Journal, 28, 247-257. https://doi.org/10. 1080/10400419.2016.1195637

Mumford A, Honey P (1992) The manual of learning styles. P. Honey, Maidenhead

Mumford, M. D. (2003). Taking stock in taking stock. Creativity Research Journal, 15, 147-151.

Nijstad, B. A., \& De Dreu, C. K. W. (2002). Creativity and group innovation. Applied Psychology, 51, 400-406. https://doi.org/10.1111/1464-0597.00984

Oman, S. K., Tumer, I. Y., Wood, K., \& Seepersad, C. (2013). A comparison of creativity and innovation metrics and sample validation through in-class design projects. Research in Engineering Design, 24, 65-92. https://doi.org/10.1007/s00163-012-0138-9

O'Quin, K., \& Besemer, S. P. (1989). The development, reliability, and validity of the revised creative product semantic scale. Creativity Research Journal, 2, 267-278. https://doi.org/10.1080/10400 418909534323

Osborn AF (1979) Applied imagination: Principles and procedures of creative problem-solving. 3 edn. Charles Scribener's Sons, New York, USA

Pahl, G., \& Beitz, W. (2013). Engineering design: A systematic approach. Springer.

Pauli, R., Mohiyeddini, C., Bray, D., Michie, F., \& Street, B. (2008). Individual differences in negative group work experiences in collaborative student learning. Educational Psychology, 28, 47-58. https://doi.org/10.1080/01443410701413746

Petersson, A. M., Lundberg, J., \& Rantatalo, M. (2017). Ideation methods applied in a cross-functional inter-organizational group: An exploratory case study from the railway sector. Research in Engineering Design, 28, 71-97. https://doi.org/10.1007/s00163-016-0238-z

Pfaff, E., \& Huddleston, P. (2003). Does It Matter if I Hate Teamwork? What Impacts Student Attitudes toward Teamwork. Journal of Marketing Education, 25, 37-45. https://doi.org/10.1177/02734 75302250571

Pollitt, A. (2012). Comparative judgement for assessment. International Journal of Technology and Design Education, 22, 157-170. https://doi.org/10.1007/s10798-011-9189-x

Popov, V., Brinkman, D., Biemans, H. J. A., Mulder, M., Kuznetsov, A., \& Noroozi, O. (2012). Multicultural student group work in higher education: An explorative case study on challenges as perceived by students. International Journal of Intercultural Relations, 36, 302-317. https://doi.org/ 10.1016/j.ijintrel.2011.09.004

Pugh, S., Clausing, D. (1996). Creating innovtive products using total design: The living legacy of Stuart Pugh. Addison-Wesley Longman Publishing Co., Inc.

Putman, V. L., \& Paulus, P. B. (2009). Brainstorming, brainstorming rules and decision making. Journal of Creative Behavior, 43, 29-40. https://doi.org/10.1002/j.2162-6057.2009.tb01304.x

Qu, L., Chen, Y., Rooij, R., \& de Jong, P. (2019). Cultivating the next generation designers: Group work in urban and regional design education. International Journal of Technology and Design Education. https://doi.org/10.1007/s10798-019-09540-6

Rauth, I., Köppen, E., Jobst, B., Meinel, C. (2010). Design thinking: An educational model towards creative confidence. In DS 66-2: Proceedings of the 1st international conference on design creativity (ICDC 2010).

Rebernik, M., Bradač, B., Rebernik, M., \& Bradač, B. (2008). Idea evaluation methods and techniques (p. 27). University of Maribor.

Reddy, Y. M., \& Andrade, H. (2010). A review of rubric use in higher education. Assessment \& Evaluation in Higher Education, 35, 435-448. https://doi.org/10.1080/02602930902862859 
Rhorbach, B. (1969). Kreative nach regeln: Methode 635, eine neue technik zum losen von problemen. Absatzwirtschaft, 12, 73-75.

Rickheim, P. L., Weaver, T. W., Flader, J. L., \& Kendall, D. M. (2002). Assessment of group versus individual diabetes education a randomized study. Diabetes Care, 25, 269-274. https://doi.org/10. 2337/diacare.25.2.269

Rietzschel, E. F., Nijstad, B. A., \& Stroebe, W. (2006). Productivity is not enough: a comparison of interactive and nominal brainstorming groups on idea generation and selection. Journal of Experimental Social Psychology, 42, 244-251. https://doi.org/10.1016/j.jesp.2005.04.005

Rietzschel, E. F., Nijstad, B. A., \& Stroebe, W. (2010). The selection of creative ideas after individual idea generation: Choosing between creativity and impact. British Journal of Psychology, 101, 47-68. https://doi.org/10.1348/000712609x414204

Sarkar, P., Chakrabarti, A. (2008). Studying engineering design creativity-developing a common definition and associated measures. In Gero, J. (Ed.), Proceedings of the NSF workshop on studying design creativity.

Sarkar, P., \& Chakrabarti, A. (2011). Assessing design creativity. Design Studies, 32, 348-383. https:// doi.org/10.1016/j.destud.2011.01.002

Shah, J. J., Smith, S. M., \& Vargas-Hernandez, N. (2003). Metrics for measuring ideation effectiveness. Design Studies, 24, 111-134. https://doi.org/10.1016/s0142-694x(02)00034-0

Shah, J. J., Vargas-Hernandez, N., Summers, J. D., \& Kulkarni, S. (2001). Collaborative sketching (C-Sketch) - an idea generation technique for engineering design. The Journal of Creative Behavior, 35, 168-198. https://doi.org/10.1002/j.2162-6057.2001.tb01045.x

Shai, O., Reich, Y., \& Rubin, D. (2009). Creative conceptual design: Extending the scope by infused design. Computer-Aided Design, 41, 117-135. https://doi.org/10.1016/j.cad.2007.11.004

Siddharth, L., \& Chakrabarti, A. (2018). Evaluating the impact of Idea-Inspire 4.0 on analogical transfer of concepts. Artificial Intelligence for Engineering Design, Analysis and Manufacturing, 32, 431-448. https://doi.org/10.1017/S0890060418000136

Starkey, E., Toh, C. A., \& Miller, S. R. (2016). Abandoning creativity: The evolution of creative ideas in engineering design course projects. Design Studies, 47, 47-72. https://doi.org/10.1016/j.destud. 2016.08.003

Stroebe W, Nijstad BA, Rietzschel EF (2010) Chapter four - beyond productivity loss in Brainstorming groups: The evolution of a question. In: Zanna MP, Olson JM (eds) Advances in experimental social psychology, vol 43. Academic Press, New Yok (pp 157-203). https://doi.org/10.1016/ S0065-2601(10)43004-X

Taggar, S. (2002). Individual creativity and group ability to utilize individual creative resources: A multilevel model. The Academy of Management Journal, 45, 315-330. https://doi.org/10.2307/3069349

Thompson, D. (2002). Assessing group projects in design education. The Design Journal, 5, 41-56. https:// doi.org/10.2752/146069202789317753

Thompson, G., \& Lordan, M. (1999). A review of creativity principles applied to engineering design. Proceedings of the Institution of Mechanical Engineers, Part E: Journal of Process Mechanical Engineering, 213, 17-31. https://doi.org/10.1243/0954408991529960

Toh, C. A., \& Miller, S. R. (2015). How engineering teams select design concepts: A view through the lens of creativity. Design Studies, 38, 111-138. https://doi.org/10.1016/j.destud.2015.03.001

Toh, C. A., \& Miller, S. R. (2016). Creativity in design teams: The influence of personality traits and risk attitudes on creative concept selection. Research in Engineering Design, 27, 73-89. https://doi.org/ 10.1007/s00163-015-0207-y

Tucker, R. (2017). Teaching teamwork in design: a framework for understanding effectiveness in student teams. In Richard T (Ed.), Collaboration and student engagement in design education. IGI Global, Hershey, PA, USA, pp 1-27. https://doi.org/10.4018/978-1-5225-0726-0.ch001

Ursachi, G., Horodnic, I. A., \& Zait, A. (2015). How reliable are measurement scales? External factors with indirect influence on reliability estimators. Procedia Economics and Finance, 20, 679-686. https:// doi.org/10.1016/S2212-5671(15)00123-9

Van Boeijen A, Daalhuizen J, van der Schoor R, Zijlstra J (2014) Delft design guide: Design strategies and methods.

Wang, S.-L., \& Lin, S. S. J. (2007). The effects of group composition of self-efficacy and collective efficacy on computer-supported collaborative learning. Computers in Human Behavior, 23, 2256-2268. https://doi.org/10.1016/j.chb.2006.03.005

Webb, N. M., \& Mastergeorge, A. (2003). Promoting effective helping behavior in peer-directed groups. International Journal of Educational Research, 39, 73-97. https://doi.org/10.1016/S0883-0355(03) 00074-0 
Wiltermuth SS (2009) Dominance complementarity and group creativity. In: Elizabeth AM, Jack AG, Margaret AN (Eds) Creativity in groups, vol 12. Research on Managing Groups and Teams. Emerald Group Publishing Limited (pp. 57-85). https://doi.org/10.1108/S1534-0856(2009)0000012006

Wong, Y. L., \& Siu, K. W. M. (2012). A model of creative design process for fostering creativity of students in design education. International Journal of Technology and Design Education, 22, 437-450. https:// doi.org/10.1007/s10798-011-9162-8

Woolard, N. A. (2018). Rethinking management group projects with the adaptive leadership model: The lesson is the process. Journal of Education for Business, 93, 392-402. https://doi.org/10.1080/08832 323.2018.1496895

Xu, M., Williams, P. J., Gu, J., \& Zhang, H. (2020). Hotspots and trends of technology education in the international journal of technology and design education: 2000-2018. International Journal of Technology and Design Education, 30, 207-224. https://doi.org/10.1007/s10798-019-09508-6

Yang, M.-Y., You, M., \& Chen, F.-C. (2005). Competencies and qualifications for industrial design jobs: Implications for design practice, education, and student career guidance. Design Studies, 26, 155189. https://doi.org/10.1016/j.destud.2004.09.003

Yilmaz, S., Daly, S. R., Seifert, C. M., \& Gonzalez, R. (2016). Evidence-based design heuristics for idea generation. Design Studies, 46, 95-124. https://doi.org/10.1016/j.destud.2016.05.001

Zhai, L.-Y., Khoo, L.-P., \& Zhong, Z.-W. (2009). Design concept evaluation in product development using rough sets and grey relation analysis. Expert Systems with Applications, 36, 7072-7079. https://doi. org/10.1016/j.eswa.2008.08.068

Zhang, W., Zhang, Q., \& Song, M. (2015). How do individual-level factors affect the creative solution formation process of teams? Creativity and Innovation Management, 24, 508-524. https://doi.org/10. 1111/caim. 12127

Zheng, X., \& Miller, S. R. (2020). Out in the field versus inside in the lab: A comparison of design professionals' concept screening practices. Journal of Mechanical Design. https://doi.org/10.1115/1.40479 04

Zwicky, F. (1969). Discovery, invention, research through the morphological approach. Macmillan.

Publisher's Note Springer Nature remains neutral with regard to jurisdictional claims in published maps and institutional affiliations. 